Click www.researchjournal.co.in/online/subdetail.html to purchase.

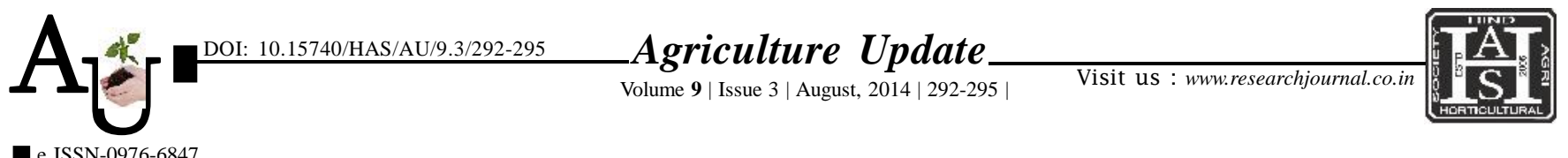

Research Paper

\title{
Role of front line demonstration on transfer of isabgol production technology in Barmer district of Rajasthan
}

\author{
口 PRADEEP PAGARIA AND S.L. KANTWA
}

Article Chronicle： Summary : The present study was conducted in Gudhamalani, Panchayat Samiti, Barmer district of Rajasthan. Received :

06.10.2012;

Revised :

21.05.2014;

Accepted :

08.06.2014

From Panchayat Samiti was selected maximum number (70) of front line demonstrations on isabgol crop conducted by Krishi Vigyan Kendra, Danta, Barmer district during the last five years (2005-06 to 2009-10). The results revealed that the average yield recorded in the FLD,s field and farmer's field was 8.50 and $6.50 \mathrm{q} / \mathrm{ha}$ ' during 2007-2008, respectively and FLDs field and farmers field lowest yield was 5.5 and 4.40 q/ha: during 2006- 2007, respectively. The result showed 30.68 to 35.24 per cent yield increase in FLDs over farmers practice during 200506 to 2009-2010. Therefore, front line demonstration programme was an effective tool for increasing the productivity of isabgol and changing knowledge, attitude and skill of farmers. This created greater awareness and motivated the other farmers to adopt improved practices of isabgol.

How to cite this article : Pagaria, Pradeep and Kantwa, S.L. (2014). Role of front line demonstration on transfer of isabgol production technology in Barmer district of Rajasthan. Agric. Update, 9(3) : 292-295.

KeY Words:

Isabgol, FLDs,

Demonstration

Author for correspondence :

PRADEEP PAGARIA

Krishi Vigyan Kendra,

Danta, BARMER

(RAJASTHAN) INDIA

Email: kvkbarmer

@yahoo.com

See end of the article for

authors' affiliations 